\title{
Environmental education and philosophy in the Anthropocene
}

\author{
David R. Cole ${ }^{1 \star \star}$ and Karen Malone ${ }^{2}$ \\ ${ }^{1}$ Western Sydney University, Sydney, New South Wales, Australia and ${ }^{2}$ Swinburne University, Melbourne, Victoria, Australia \\ ${ }^{\star}$ Corresponding author. Email: david.cole@westernsydney.edu.au
}

(Received 30 November 2019; accepted 06 January 2020)

We stand on the cusp of a new era, called the 'Anthropocene'. Some date the beginnings of the Anthropocene back to the industrial revolution in the United Kingdom and elsewhere at the end of the 18th century (e.g., Tsing, 2015). Others place it alongside the great acceleration that has occurred after the end of the World War II, and 1945 (Steffen, Broadgate, Deutsch, Gaffney, \& Ludwig, 2015). Others still look to the basic drives of humans, and how humans have used their social intelligence to understand, transform and ultimately dominate nature (Ellis, 2015). The disruption that the naming of the Anthropocene has administered in environmental education and will continue to administer - has provided a massive jolt to our collective imagination. As an unsettling ontology that disrupts a persistent 'humanist' paradigm, the concept of the Anthropocene has allowed new conversations around human-dominated global change, human exceptionalism and the nature-culture divide. It has been employed as a heuristic device for gaining a greater understanding of the role of human societies and the part they have played in changing the planet. Therefore, the starting point of and for the Anthropocene is less important to this special edition than two fundamental questions that the naming of the new era produces: (1) What does the Anthropocene mean for the future of human civilisation (and, for example, education)?

(2) What can and should be done with respect to the Anthropocene?

This special edition takes on one small aspect of the possible responses to these questions entailed by 'Environmental education and its philosophy'. It is the contention of this special edition that the naming of the Anthropocene marks an awakening and a significant moment for environmental education. The significance and overwhelming reality of the Anthropocene, and its connections to, for example, the sixth great extinction event (e.g., Kolbert, 2014), making learning about, in, and how to deal with the environment more important than ever. Philosophy, as the fundamental mode of human speculation about life, is a fitting companion to an expanded and centralised environmental education and acts as a basic driver for education in the Anthropocene. Philosophy does not discriminate between subject disciplines and can work to galvanise all the resources available to respond to the problematics of the Anthropocene if applied evenly. Philosophically, the Anthropocene is a concept that works both for us and on us. In its unsettlement of the entrenched binaries of modernity (human-nature, nature-culture, objectsubject) and its provocative alienation of familiar anthropocentric scales and times opens up possibilities for exploring new theoretical approaches such as posthumanism and new materialism. In this special issue, many of the articles have an underlying focus on fleshing out what it means to be human in a world where being human is being disrupted, interrogated; exploring the precarity and promise of a human being in a constant and dynamic state of ontological becoming as (merely) part of the material world and subject to the same physical processes. Vital materiality, agential 
realism - all open up new theoretical space for exploring these concepts as it acknowledges the aliveness of matter - active, self-creative, productive, unpredictable. Matter as alive means we can no longer delineate the 'human' body as an island but human as a species, one among many, as it becomes an assemblage of objects cellular and historical. Guattari describes this move from a postnuclear model of embodied subjectivity entering into a 'viral' or 'parasitic' mode as a discerning shift in paradigms, raising ontological questions of what it means to be in the world with shared bodies through time. The world, as used with this approach, is viewed as dynamic, in a constant process of 'being' and 'becoming' with material matter. Intra-action, as presented through the thinking of Barad (2007), constitutes a reconfiguring of 'things' and 'objects' that are not structured with a specific space or time but are enacted as agential entities flowing in a space-time continuum. The focus of reality in this approach is not on the phenomena of the things (their specific properties) but how the things are 'in-phenomena' - being produced through a series of entangled relational possibilities with other objects and things.

Philosophy can be taught and understood from an early age if it is included in the curriculum, as subjects such as Philosophy 4 Children (P4C) have demonstrated (Topping \& Trickey, 2007). If there is one problem that requires philosophy right now, it is the Anthropocene, and similar to environmental education, surely the time has come for an overhaul and adaptation of the practice of philosophy, away from marginalised and neglected corridors of universities, colleges and schools that hardly see any funding, to an essential practice to enable coherent thought in the Anthropocene. Of course, there are many shades and varieties of philosophy that could accompany the Anthropocene and environmental education, and this special edition cannot hope to cover all of them. However, as an initial foray into this field, this special edition does serve to highlight the ways in which philosophy and environmental education cohere and bring to the fore the ways in which the Anthropocene by its very nature is changing the ways in which we think and educate. At the very least, the Anthropocene is a threshold that makes us (re)consider our existence, responsibilities and actions with respect to how we live. So, it is in the spirit of thinking that something can be done in and about the Anthropocene that this special edition collects essays on philosophy and environmental education to enable and guide possible throughlines for these changes.

\section{Environmental education, philosophy, and the politics of the anthropocene The politics of realism}

What is climate change? Is it an object that can be easily understood? How can we study and educate about it? These questions bring to mind the perspective of realism, which is usually associated with science, and the objective study of the world (by humans). Previously, much of environmental education was involved with the practical translation of environmental science into pedagogy (e.g., Stevenson, 2007). When it came to climate change, the problem was seen as being how to package the information about global warming in a way that was digestible and clear for students. Now, with the advent of the Anthropocene and the failure of previous strategies to make the necessary ecological changes in society, this special edition attends to new ways to conceive of climate change that may have a better chance of penetrating general opinion and enacting societal change. One of these approaches is to reconceive of climate change as a hyperobject (Morton, 2013). The article by Bradley in this special edition critiques the hyperobject as mystifying climate change, while the article by Bazzul takes a different stance on the hyperobject and puts it to work to exemplify a mode of 'ontological play', to make us think differently about climate change. Bradley's critique states that the 'nonrealism' of Morton's hyperobject makes climate change unknowable, and action to arrest it henceforth impossible to organise. Bazzul argues that hyperobjects act to disrupt assumptions and normative ways of doing things that could be essential for a revised environmental education and a different realism for the Anthropocene. 
Mirzaei Rafe et al. take arguments from the philosophy of science of Roy Bhaskar (1978), which conjoins realism with critical theory to produce 'critical realism'. Critical realism asserts that climate change is knowable, but that reality is planar; that is, there are many different levels through and by which climate change is knowable and will act, and on the human plane, a dialectics between different social groups is essential to enable agency about climate change (by, for example, talking about climate change injustices). Bradley takes a similar path out of the politics of realism, in that he argues that we need to align action on climate change with an enhanced and revitalised rationality, that, for example, takes the ancient animist traditions of Japan and applies them for a new environmental education, mixing critical theory about the economy and politics with enhanced sensitivity in nature and the ritualised practices of nature-worship in Shinto. Bazzul's approach to environmental education differs in that he wants to reimagine realism along the lines of Morton's romantic science, and produce assemblages of climate change educational action (learning) whereby the imaginations and thinking faculties of the students are fully challenged and enlivened. Mirzaei Rafe et al. construct interdisciplinary units of work that unite the realist with the critical, to enable thought around social change in times of climate change, and which draws us into a critical approach to the Anthropocene.

\section{Critical theory in the Anthropocene}

Critical theory has a long history that goes back at least to the work of Karl Marx (1818-1883). Realism asks what is climate change? Critical theory asks what are the mechanisms underlying climate change - for example, capitalism and neoliberalism (e.g., Moore, 2015)? Critical theory attempts to critically analyse these mechanisms and come up with pedagogies that suit such an investigation, which have been variously defined within the rubric of critical pedagogy (e.g., McLaren, 1998). For this special edition, the articles by Bradley, Boxley, Mirzaei Rafe et al. and Cole engage with critical theory in different ways. As has been mentioned, Bradley mixes critical theory with Japanese animism and phenomenology to understand how society can change (and think) ecologically in the Anthropocene, to steer a new path away from total collapse. Boxley envisages a bold new vision for environmental education, based on marrying Marxism with deep ecology. Boxley calls his new practice for environmental education 'Red Biocentrism' and insists that the Anthropocene calls for such radical rethinking, as society must come to terms with the new conditions of the Anthropocene. Clearly, this Red Biocentrism is deeply political and calls into question the ways in which human activity and thinking is currently dominated in and through capitalism. Boxley asserts that it is only by taking the political dimensions of the current environmental crisis seriously and conjoining them with deep ecological (and biological) concerns that society will change. Red Biocentrism, if taken literally, has many implications for environmental education, some of which have been sketched out in the article, which serve as a blueprint for wholesale societal eco-revolution.

Mirzaei Rafe et al. take a more conservative approach to applying and using critical theory than Boxley in that they identify interdisciplinary, educational learning units that first question the nature of climate change (realism), and second, apply these insights into investigating the mechanisms of social change (critical theory). Mirzaei Rafe et al. suggest a rounded and philosophical approach to joining realism with critical theory that would give educators the opportunity to purposefully do work with their cohorts that encourages the groups to become motivated actors and climate change activists. Bhaskar (1978) was concerned that his theory of critical realism enabled agency, and this can be clearly seen in the four interrelated units of work that Mirzaei at al. have produced in their article. In contrast, Cole takes a Deleuzian line with respect to environmental education in the Anthropocene that focuses on conceptual ways of enhancing and recalibrating the actions of the group, such as assemblages, and through rhizomes. Deleuze includes a Marxian analysis of society in his synthesis, but focuses on how it works in and on the unconscious and imaginary. Cole suggests that this philosophical approach to teaching and learning would have 
beneficial effects if applied to environmental education in that it enables a thinking mode of critical theory that has the potential to go beyond the human.

\section{Postcolonialism in the Anthropocene}

Critical theory enables and encourages investigation into the mechanisms of the Anthropocene; for example, economics. One of these mechanisms is connected to the history of colonialisation and how Indigenous peoples around the world have been dominated, exploited, exterminated and marginalised in the very countries that they have occupied for many thousands of years before the European invaders. It is being increasingly recognised that Indigenous peoples hold knowledge, understanding and practices that are closely aligned to the needs of the countries where they have lived for millennia, and that mainstream society should take note of and utilise, especially in times of environmental catastrophe (e.g., Davis \& Todd, 2017). Education as a system and discipline can be slow to react to such changes and imperatives, and Indigenous knowledges and practices are frequently sidelined to the periphery in curricula dominated by mainstream Western concerns such as numeracy and literacy. The two articles included in this special edition by Stein and Thornton, Graham \& Burgh argue that Indigenous knowledges should be included as part of mainstream education to encourage new ways to look at and act on climate change.

Stein argues that colonialism is the active cause of climate change. She believes that nothing will change unless this fact is admitted and acted upon, and that the establishment of the institutional sustainability response to climate change is part of the denial mechanisms of colonialism and the inability to break with the habits of mind that are constituted by colonialism. Stein looks to the processes of decolonial thought to help us navigate out of the colonial trap, and specifically applies decolonial thought to university practices. Stein's argument is a passionate plea to think otherwise in the current situation of the Anthropocene, and to allow for and encourage different types of knowledges and thinking practices into the frame, to help pull us away from inevitable environmental disaster based on, for example, the logic and domination of capitalist economics. Thornton similarly argues against mainstream colonial education, and looks to enable a new decolonial discourse for the Anthropocene in Australia by putting to work feminism, environmentalism and philosophy. Thornton suggests that in Australia, the knowledges, experiences and practices of Aboriginal Australians is an invaluable resource that should be mobilised in times of climate crisis called the Anthropocene. For example, the ways that Aboriginal peoples have deliberately worked with fire in the environment have a subtlety and specificity that could be very helpful in the current scenario of drought and rising temperatures due to global warming. Thornton suggests that white settlers in Australia have initiated and maintained a mode of thought and practice that is seen, for example, in the education system, which acts as an exclusionary device wherein Aboriginality is pushed to the outside. Challenging this mode of thought and acting otherwise is an imperative made all the more real by the impending environmental disaster looming for Australia in the Anthropocene and its causes, such as the burning of fossil fuels.

\section{Posthuman and new materialist approaches in the Anthropocene}

Deleuze and Guattari (1994, p. 5) wrote in 1994:

Philosophy is not a simple art of forming, inventing or fabricating concepts, because concepts are not necessarily forms, discoveries, or products. More rigorously, philosophy is the discipline that involves creating concepts that are always new. Concepts are not waiting for us readymade, like heavenly bodies. There is no heaven for concepts.

Posthuman and new materialist approaches are not so much concerned with the question 'What does a concept mean?' but 'How does it work?'. The teaching of concepts tends to involve 
'discovering' what the linguistic concept refers to in the world. But as Deleuze and Guattari remind us, concepts are 'man-made' constructions, and they do the ontological work of reinforcing the modernist idea that there is a world 'out there', waiting to be discovered. The core philosophical assumption in this dualist paradigm is that a concept accurately represents the object in the world - a world that supposedly exists separately from the knowing subject who acquires knowledge through passive observation and is largely an individualistic enterprise (Benjamin \& Echeverria, 1992). Deleuze and Guattari's philosophy of immanence and the relational ontology of critical posthumanism, as discussed by theorists such as Karen Barad (2007), Rosi Braidotti (2013) and Donna Haraway (2016) are explored in varying ways in all the articles in this issue; in particular, by Cole, Bradley, Stein, Bazzul, Riley \& White and Mirzaei Rafe et al., when looking to disrupt hegemonic educational theories and practices through the emergence of new forms of conceptual thinking. In environmental education, concepts as overarching core beliefs (particularly moral and ethical considerations) have often been treated as 'givens' and as 'transmittable' from teacher to learner, learner to life/living in/relations with the world. This works with the idea that there is not only one language that interprets, represents and defines what a concept is assigning it an essence. MacLure (2013) points out 'to return to the logic of representation, where words "refer" to entities as if they were separate and distinct from one another' (p. 661).

Central to the posthumanist hubris is the conceptual framing for rejecting human exceptionalism. Past theories, such as those seen in the works of Spinoza in the 17th century, and philosophers Derrida, Deleuze and Guattari, ecophilosophers such as Naess, and ecofeminists Plumwood and Merchant in the 20th century (Malone, Duhn, \& Tesar, 2018), have explored commonalities across their philosophies, particularly those tendrils of rejecting human exceptionalism. Spinoza's philosophies, for example, demonstrate respect for all things, promoting the connection of human-nature and without privileging humans over nature. For Spinoza, there are only differences of degree between humans, animals, machines and rocks, but these differences are of our natural essence, and while he is often critiqued for his view that animals are lesser beings than humans, his concern seems to be to ensure there is a boundary between 'man' and 'beast', therefore not rendering 'man' as uncultivated and wild. Derrida, among others, has promoted fundamental change from the humanist views that dominated in the 20th century where humans are privileged (Braidotti, 2013). Deleuze and Guattari (1987) also rejected the separation of humans from other matter, proposing the notion of the underground rhizome to illustrate the interconnection of all matter. This rhizomatic arrangement of atoms and molecules composes all things and connects us in the cycle of life and death (Deleuze \& Guattari, 1987). Derrida, among others, promoted fundamental change from the humanist views that dominated in the 20th century where humans are privileged (Braidotti, 2013). Norwegian philosopher Arne Naess, who began in 1973 to promote ecosophy, or deep ecology, as a comprehensive, integrative philosophical inquiry, wrote, 'By an ecosophy I mean a philosophy of ecological harmony or equilibrium' (Naess, 1973, p. 99). The ecofeminist argument presented by Val Plumwood in her 1993 classic, Feminism and the Mastery of Nature, argued that deep ecology as presented by Naess did not go far enough to encompass the vast human-nonhuman experience. Ariel Salleh joined Plumwood in mounting an ecofeminist critique of deep ecology (Plumwood, 1993; Salleh, 1984, 1992), with many ecofeminists accusing deep ecology of a masculine bias. Braidotti (2013) picks up this line of thought in her book The Posthuman, where she claims a Gaian masculinist view of deep ecology is a regressive movement that 'humanizes the environment' and becomes 'a well-meaning form of anthromorphic normativity being applied to non-human planetary agents' (Braidotti, 2013, p. 85).

The authors in this issue take up these past tracings of philosophical thought explicitly or sometimes not so explicitly by identifying the distinct role philosophical approaches such as posthumanism and new materialist could take up as navigational tools (Braidotti, 2013) for a 'new' imaginary of Western-orientated environmental education. The papers by Riley \& White, Thornton, Graham \& Burgh, Postila and Germein \& Vaishnava especially take up this 
challenge. As environmental educators embrace the naming of the Anthropocene and how it is working on us, it has the potential to move the field beyond predefined boundaries, assumed categories of difference and language, therefore allowing for reforming and reconfiguring new philosophical spaces for environmental education.

\section{References}

Barad, K. (2007). Meeting the universe halfway: Quantum physics and the entanglement of matter and meaning. Durham, NC: Duke University Press.

Benjamin, M., \& Echeverria, E. (1992). Knowledge and the classroom. In A. Sharp \& R. Reed (Eds.), Studies in philosophy for children: Harry Stottlemeier's discovery (pp. 103-122). Philadelphia, PA: Temple University Press.

Bhaskar, R. (1978). A realist theory of science. Brighton, UK: Harvester Press.

Braidotti, R. (2013). The posthuman. Cambridge, UK: Polity Press.

Davis, H., \& Todd, Z. (2017). On the importance of a date, or decolonizing the Anthropocene. ACME: An International E-Journal for Critical Geographies, 16, 761-778.

Deleuze, G., \& Guattari, F. (1987). A thousand plateaus: Capitalism and schizophrenia. Minneapolis, MN: University of Minnesota Press.

Deleuze, G., \& Guattari, F. (1994). What is philosophy? (H. Tomlinson \& G. Burchell, Trans.). New York, NY: Columbia University Press.

Ellis, E.C. (2015). Ecology in an anthropogenic biosphere. Ecological Monographs, 85, 287-331.

Haraway, D.J. (2016). Staying with the trouble: Making kin in the Chthulucene. Durham, NC: Duke University Press.

Kolbert, E. (2014). The sixth extinction: An unnatural history. New York, NY: Henry Holt.

McLaren, P. (1998). Revolutionary pedagogy in post-revolutionary times: Rethinking the political economy of critical education. Educational Theory, 48, 431-462.

MacLure, M. (2013). The wonder of data. Cultural Studies $\leftrightarrow$ Critical Methodologies, 13, $228-232$.

Malone, K., Duhn, I., \& Tesar, M. (2018). Greedy bags of childhoodnature theories. In A. Cutter-Mackenzie-Knowles, K. Malone, \& E. Barratt Hacking (Eds.), Research handbook on childhoodnature: Assemblages of childhood and nature research. Cham, Switzerland: Springer International Publishing.

Moore, J. (2015). Capitalism in the web of life: Ecology and the accumulation of capital. London, UK: Verso.

Morton, T. (2013). Hyperobjects: Philosophy and ecology after the end of the world. Minneapolis, MN: University of Minnesota Press.

Naess, A. (1973). The shallow and the deep, long-range ecology movement: A summary. Inquiry, 16, 95-100.

Plumwood, V. (1993) Feminism and the mastery of Nature. New York, NY: Routledge.

Salleh, A. (1984). Deeper than deep ecology: The ecofeminist connection. Environmental Ethics, 6, 335-341.

Salleh, A. (1992). Class, race and gender discourse in the Deep Ecology/Ecofeminism debate. Environmental Ethics, 14, 195-216.

Steffen, W., Broadgate, L., Deutsch, O., Gaffney, O., \& Ludwig, C. (2015). The trajectory of the Anthropocene: The great acceleration. The Anthropocene Review, 2, 81-98.

Stevenson, R.B. (2007). Schooling and environmental education: Contradictions in purpose and practice. Environmental Education Research, 13, 139-153.

Topping, K.J., \& Trickey, S. (2007). Collaborative philosophical enquiry for school children: Cognitive gains at two-year follow-up. British Journal of Educational Psychology, 77, 787-796.

Tsing, A. (2015). The mushroom at the end of the world: On the possibility of life in capitalist ruins. Princeton, NJ: Princeton University Press.

Cite this article: Cole DR and Malone K (2019). Environmental education and philosophy in the Anthropocene. Australian Journal of Environmental Education 35, 157-162. https://doi.org/10.1017/aee.2020.5 